\title{
Classification and Characteristics of Historical Learning Media
}

\author{
$\mathrm{Aksa}^{1}$ \\ ${ }^{1}$ Mulawarman University, Banggeris Street, 89, Samarinda, Indonesia
}

\begin{abstract}
Conventional learning is deemed less appropriate to the dynamics of the development of science and technology. In an effort to improve the learning process in accordance with the needs and development of the era, the function of learning media is very important to be utilized. Therefore, classifying and mapping based on media characteristic, is required for the media to be used in historical learning. Based on its category, the media can be grouped into audio visual media motion, silent audio visual media, semi-motion audio media, visual media motion, silent visual media, semimotion media, audio media, and print media. Historical learning media can also be grouped based on technology, like printed media, audio-visual technology, computerbased technology, and mixed media of print and computer technology. Each of these media groups has distinctive characteristics that differ from each other. In general, there are three characteristics of instructional media for its use to be more effective and efficient, such as the manipulative characteristics and distributive characteristics. Thus, the characteristics of media, media classification, and media selection are an integral part in the determination of learning strategies, especially in historical learning.
\end{abstract}

\section{Keywords: Media Classification; Media Characteristics; Historical Learning}

\section{INTRODUCTION}

Conventional learning system (faculty teaching) rated with instructional atmosphere and felt less in accordance with the dynamics of the development of science and technology. Moreover, the obligation of education required also to incorporate moral values, character, creativity, independence, and leadership, which is very hard to do in a conventional learning system. The conventional learning system is less flexible in accommodating the development of material competence because teachers should adjust the intensive subject matter with the latest technological developments. It is less sensible if technological development is much faster than the ability of teachers in adjusting the material competence with such developments, thus ensuring that graduates will have less mastery of knowledge/latest technology.

In the process of learning teachers in school usually just use printed books are distributed to students and students just instructed to work on the appropriate page of the material or subject matter being taught. As in the lessons of history, it is still very minimal teacher use learning media in learning activities. There are several fundamental reasons that cause such as the ability to operate media, electronic is still low, the knowledge of the media learning still less, as well as the lack of information obtained about the media teacher learning. This is in accordance with the opinion of the learning 
method that Herianto conventional applied by the teachers have formed a negative student character, whereas the use of media in learning has brought reason students towards better [1].

In an attempt to improve the learning process to be effective and functional, then the function of the media is very important for the learning is utilized. The use of the media in the process of learning is intended to heighten student power against the information or learning materials provided. The Government has long been aware that the role of the media in the process of learning is very important. Therefore, it has a lot of the funds invested to improve the quality of education in various ways, such as through procurement or distribution of a wide variety of media of instruction in schools across Indonesia. The effectiveness of the use of the media learning depends very much on the degree of conformity with the material to be taught. However, the effective use of the media or whether learning depends also on the expertise of teachers in using the media. Dick and Carey stated that one of the most important decisions in designing learning is by using the appropriate media in order to delivery of learning messages [2]. Similarly, with the Dick and Carey, Miarso argued that a well-designed media within a certain limit can stimulate some kind of internal dialogue within the student learning [3]. In other words, communication occurs between students with media or indirectly between students with the message source or teacher. The media managed to bring the message of learning if then there is a change in the quality of students. Therefore, the use of media of instruction in the learning process has a significance including a history lesson.

\section{RESEARCH METHOD}

The steps are compiled from the heuristics or data by searching the data in this case which searches for books that have relevance to the written ones. After the concise books are verified and interpreted and then in the form of writing. This writing is the result of critical analysis and supported by the data generated through literature study, this paper is processed and analyzed from the reading that is in the books about the media learning. Through the learning media, teachers are expected to apply to their students in history learning.

\section{MEDIA IN LEARNING HISTORY}

Instructional Media or props, known as one of the tools in the learning activities. Said to be a tool because it functions as a tool for helping teachers in smoothing the path of teaching, so as to clarify the understanding of the students to the materials being studied. The tool is a great way to present a subject matter through demonstration. According to media sediment is anything that can be used to transmit a message from the sender to the recipient so that it can stimulate the thoughts, feelings, concerns, and interests as well as the attention of students such that the process of teaching and learning happen effectively and efficiently [4].

While Hamalik gives a sense that the media are tools, methods, and techniques used in order to better streamline communication and interaction between teachers and students in the process of education and teaching in school [5]. From the notion, can be 
put forward that what is meant by tools or media in learning are all tools that can be used by teachers or lecturers and students reach the objectives that have been determined. Thus, the definition of media in learning history is a tool or an intermediary used by the teacher to deliver the subject matter or channeling messages from the sender to the receiver so as to stimulate the interest and attention of students in teaching and learning activities to achieve the objectives that have been determined.

But the thing to note on the use of media in learning history is the principle there is no one else that most media is good for the overall problem or the purpose of teaching. For every media have different characteristics, each of which has strengths and weaknesses. Therefore, in the selection of media should be adapted to the purpose, the ability of the students, the nature of the material, and the teacher's ability in running the media. So, actually there is not a medium that can be used by all sorts of situations and conditions. Based on the above description, it is clear that the media is a tool that became the introduction in the achievement of learning objectives. Thus, it is the history of learning media are a tool that can be used by teachers and students in teaching and learning to achieve the expected learning.

\section{THE CLASSIFICATION OF MEDIA IN LEARNING HISTORY}

Media learning instructional component includes messages, people, and equipment. With the introduction of various influences into the world of education (for example new concepts and theory/technology), media education (Learning) continue to grow and appear in a variety of types and formats, with their respective characteristics and its own merits. It was here that then arise from attempts to do a classification or grouping of media, which led to the creation of the taxonomy of media education/learning.

Efforts toward the media taxonomy have been made by some experts. Rudy Bretz, classifies media based on element anyway, i.e. voice, visual (in the form of pictures, lines, and symbols), and motion. In addition, Bretz distinguishes between broadcast media (telecommunication) and media record (recording). Thus, the media, according to taxonomy grouped Bretz 8 categories: a) the audiovisual media motion, b) audio visual media, audio media c) spring motion, d) visual media motion, e) visual media silence, f) spring motion media, audio media), $g$ and $h$ ) printed.

Groupings according to the level of complexity of media devices, particularly the audio-visual media, performed by c. j. Duncan, with a crafting a hierarchy. Of hierarchy represented by Duncan can be drawn a conclusion that the higher the level of a hierarchy of media, the lower the unit cost and the more specialized nature of their use. However, the ease and flexibility of usage are increasingly growing. Vice versa, if a medium is at the lowest hierarchy. Schramm [6] also do a grouping of media based on the level of complexity and the magnitude of the cost. In this case, according to Schramm, two big media namely media group (complicated and expensive) and little media (simple and cheap). Furthermore, these experts mention there's mass media, the media group, the media, and individuals, based upon power tickets for the media.

Some other experts like Gagne, Briggs, Edling, and Allen, made media with taxonomic considerations that focus more on the process and interaction in learning, rather than the nature of the medium itself. Gagne for example, classify a medium based on the level of the developmental learning hierarchy [8]. According to him, there are 7 different media groups such as: objects for oral communication demonstrated, print, still 
images, motion pictures, movie sound, and machine learning. Briggs became media classifies the 13 types of compliance based on stimulation of the media with the characteristics of the students. The thirteenth such media types are: object/real objects, models, direct sound, audio recordings, printed media, hard-wired Learning, Blackboard, media transparency, film frames, film $(16 \mathrm{~mm})$, movie sets, televisions, and images (graphics).

In line with technological developments, then the learning media development experience through utilization of the technology itself. Based on these technological developments, Arsyad [7] classify media in four groups: 1) print technology results, media 2) media audio-visual technology results, 3) media the results of computer-based technology, and 4 combined results) media print technology and computers. Seels and Glasgow [7] divide the media into two major groups, namely: traditional media and media technologies. A selection of traditional media in the form of visual media silence is not projected and projected, audio, multimedia, dynamic visual presentation which projected, print, games, and media reality. Whereas the choice of the latest technologies in the form of media-based telecommunications media (e.g. Teleconferences) and microprocessor-based media (e.g. Computer games and hypermedia).

Grouping of several media expressed above, it seems that up to now this has not been an agreement on classification system (taxonomy) of raw media. In other words, there has been no public media taxonomy and include all its aspects, especially for an instructional system (learning). Or indeed there will never be a system of classification or grouping is valid and generally accepted. Nevertheless, whatever and however way is classified as media, they provide information about the specifics of the very media we need to know. The grouping of existing media at this point can clarify the difference of purpose of use, function and its ability, so it can be used as guidelines in choosing the appropriate media for a specific Learning.

\section{THE CHARACTERISTICS OF THE MEDIA IN LEARNING HISTORY}

Each Learning media has certain characteristics, which is associated or the views of the various establishments. For example, Schramm saw the media in terms of its economic characteristics, the scope targets can be covered, and the ease of control by the wearer [6]. The characteristics of the media can also be seen, according to their ability to evoke sensory stimulation throughout the tool. In this case, the knowledge about the characteristics of the medium of instruction is very important for the grouping and selection of media. Kemp, 1975 [6], also suggested that the media characteristics are the basis of election media tailored to the particular learning situation.

Gerlach and Ely suggest three characteristics of the media based on media usage instructions learning to anticipate the conditions of learning where teachers are unable or less able to do so effectively. The third characteristic or characteristics of the Learning media [7] is: a hallmark of fixative), which describes the ability of the media to record, store, preserve, and reconstructing an event or object; b) characteristic of manipulative, namely media capabilities to transform an object, event or process in addressing the problems of space and time. For example, suppose a process larvae become pupae and then into a butterfly can be presented with less time (accelerated with time-lapse recording techniques). Or rather, an event/events can be slowed down so that it obtained a clear sequence of events/events; c) hallmark distributive, which 
describes the capability of transporting a media object or event through space, and simultaneously the incident served to a large number of students, in various places, with the relative experience of the same stimulus regarding the incident.

Based on the previous description, it turns out that the characteristics of the media, the classification of the media, and media selection is a single entity which is not integral in determining the learning strategies. Many experts, such as Bretz, Duncan, Briggs, Gagne, Edling, Schramm, and Kemp, have done a grouping or create the taxonomy about the learning media. Of the grouping, generally can be classified upon Learning media: media graphics, audio media, media projections of silent (only accentuate visual only and is accompanied by audio recordings), and game mediasimulation. Arsyad [7] Learning media classify into four groups based on technology, including: media, media print technology results of audio-visual technology, media technology based on the results of the computer, and the combined results of media print technology and computers. Each of these media groups has distinctive characteristics and different from one another. Characteristics of each media group will be discussed in the next description.

\section{Graphic Media}

In principle, all types of media in this group is delivering a message through visual symbols and involves stimulation of the sense of vision. Characteristics that are owned are: are concrete, can overcome the limitations of time and space, can clarify an issue in the field of problem anything and at any age level, cheap price and easy to get and use them, sometimes have characterized the abstract (in the media type diagram), is a visual summary of a process, sometimes using verbal symbols (in graphic media types), and contain a message that is both an interpretive.

\section{Audio Media}

The nature of the media types in this group are in the form of the message conveyed or poured into symbols auditive (verbal and/or non-verbal), which involves stimulation of the sense of hearing. Audio media in general have characteristics or traits as follows: able to overcome the limitations of time and space (easily moved and broad scope), messages/programs can be recorded and played back as he pleases, can develop the power of the imagination and stimulate the active participation of listeners, can overcome the problem of shortage of teachers, the nature of communication in one direction only, very appropriate for the Learning of music and language, and message/information or programs tied to the broadcast schedule (on the radio media types).

\section{Projection Media Silent}

Several types of media, including these groups, require tools (such as projectors) in a serving. There are times when the media are only presented with visual appearance alone, or accompanied by audio recordings. The General characteristics of the media is the same message can be spread to the rest of students simultaneously, has been in the control of teachers, how easy saving of (practically), can overcome the limitations of 
space, time, and the senses, presents objects silently (on media with visual appearance only), sometimes in the dark room, the need has become more expensive than graphic media group, according to teach certain skills, according to study in groups or individually, practical use for all size classes, are able to present the theory and practice of integrated, using the techniques of color, animation, motion is slow to display specific events/objects (especially in media type film), the film is more realistic and media, can be repeated, stopped, etc., according to your needs.

\section{Media Game and Simulation}

There are several other terms for these learning media groups, such as simulations and role-playing, or simulation games. Although different, everything can be grouped into one term, i.e. game [6]. Traits or characteristics of this medium is: the learners actively involved in the learning process, the role of the teacher is not so visible but that stands out is the activity of the learners interaction, it can provide immediate feedback, allowing the application of concepts or roles into the real situation in the society, has flexible because it can be used for a variety of purposes Learning by changing tools and little debate, able to improve the learners communicative, able to overcome the limitations of the learners a difficult study with traditional method, and in served and easily created and reproduced.

\section{CONCLUSION}

Student involvement in learning activities is very important, because according to experience level in the classification of the most concrete to the abstract, where the most participation, observation, and experience gives huge influence against the accepted students learning experience. The submission of a concept in students will be carried out well if the concept requires that students engage directly in it compared with the concept that only involves students to observe only. Thus, do the classification and mapping the media learning characteristic media needs required to, so the use of media of instruction is expected to give a more concrete learning experience to students. Students can also increase the liveliness and his creativity in learning history. As an example of the use of media history through an interactive computer learning.

\section{REFERENCES}

[1] Herianto.2008. Perencanaan Pengajaran.Jakarta: Rineka Cipta.

[2] Lamudji, 2005. Pengaruh Penggunaan OHP terhadap Hasil Belajar Matematikan pada Siswa Sekolah Menengah Pertama yang Bermotivasi Tinggi dan Rendah. Tesis tidak diterbitkan. Malang: Program Pascasarjana Universitas Negeri Malang.

[3] Miarso, Y. 1984. Teknologi Komunikasi Pendidikan, Pengertian dan Penerapannya di Indonesia. Jakarta: Rajawali.

[4] Sadiman. 1984. Media Pendidikan; Pengertian, Pengembangan, dan Pemanfaatan. Jakarta: Rajawali Pers

[5] Hamalik, Oemar. 1989. Media Pendidikan. Bandung: Alumni.

[6] Sadiman, A.S., Rahardjo, R., Haryono, A., \& Rahadjito. 1990. Media Pendidikan: Pengertian, Pengembangan dan Pemanfaatannya, edisi 1. Jakarta: Penerbit CV Rajawali.

[7] Arsyad, A. 2002. Media Pengajaran, edisi 1. Jakarta: PT Raja Grafindo Persada. 
[8] Gagne, R. M. 1985. The Condition of Learning and Theory of Instruction, $4^{\text {th }}$ ed. New York: CBS College Publishing. 